Ritrýnd grein birt 11. júní 2019

\title{
Stærðfræðikunnátta nema við upphaf kennaranáms. Samanburður áranna 1992 og 2014
}

\author{
Freyja Hreinsdóttir og Friðrik Diego
}

\begin{abstract}
Um höfundana $>$ About the authors Heimildir
Haustið 2014 var gerð könnun á stærðfræðikunnáttu nýnema við Kennaradeild Menntavísindasviðs Háskóla Íslands. Lagður var fyrir listi með spurningum úr hefðbundinni grunnskólastærðfræði sem áður hafði verið lagður fyrir árið 1992. Í greininni er sagt frá helstu niðurstöðum og árangur pátttakenda árið 2014 borinn saman við árangur peirra sem preyttu sama könnunarpróf 22 árum áður. Niðurstöður árið 1992 ollu vonbrigðum og áhyggjum rannsakenda, frammistaða pátttakenda reyndist að flestu leyti lakari en búist var við. Árið 2014 reyndist árangurinn enn lakari en áđur pví meðaltal hlutfalls réttra svara fór úr 53\% niður í 44\%. Ýmsar nýlegar rannsóknir og skýrslur gefa einnig til kynna að stærðfræðilegan undirbúning grunnskólakennara purfi að auka og bæta. Í porra tilfella er formlegt stærðfræðinám grunnskólakennara lítið umfram pað stærðfræðinám sem peir búa að úr grunn- og framhaldsskóla. Staða nýnema er pví verðugt athugunarefni par sem fæestir peirra bæta við sig miklu námi í stærðfræði í kennaranámi. Í greininni eru settar fram hugleiðingar um viðbrögð við niðurstöðum könnunarinnar.
\end{abstract}

Efnisorð: Kennaranám, stærðfræðikunnátta kennaranema, menntun stærðfræðikennara, könnunarpróf við Háskóla Íslands.

\section{Inngangur}

Á undanförnum árum hefur töluvert farið fyrir rannsóknum á stöðu nemenda í íslensku skólakerfi og mikill áhugi virðist á að meta skólastarf. Á priggja ára fresti er PISA-rannsóknin gerð meðal 15 ára nemenda. Meðal einkenna hennar eru hinar endurteknu mælingar, að hluta til eru sömu verkefni lögð fyrir aftur og aftur í peirri rannsókn svo hægt er að meta breytingar á færni í tíma (Almar M. Halldórsson, Ragnar F. Ólafsson og Júlíus K. Björnsson, 2013). Gengi íslenskra nemenda í stærðfræði hefur farið versnandi frá árinu 2003.

Ýmsar háskóladeildir gera athuganir á stöðu nýnema og hér skal nefnt að Verkfræði- og náttúruvísindasvið Háskóla Íslands hefur um árabil lagt könnunarpróf í stærðfræði fyrir nýnema (Anna Helga Jónsdóttir, Freyja Hreinsdóttir, Guðrún Geirsdóttir, Rögnvaldur Möller og Gunnar Stefánsson, 2013). Í ljós hefur komið að undirbúningur nýnema er mjög misjafn eftir skólum og í mörgum tilvikum ábótavant. 
Árið 1992 voru nokkrar spurningar úr grunnskólastærðfræði lagðar fyrir kennaranema á öðru misseri í janúar pað ár (sjá viðauka). Dessari athugun frá 1992 og niðurstöðum hennar voru gerð skil í skýrslu Rannsóknarstofnunar Kennaraháskóla Íslands nr. 1 (Friðrik Diego og Kristín Halla Jónsdóttir, 1994). Haustið 2014 var sama könnun lögð fyrir nema við upphaf kennaranáms við Kennaradeild Menntavísindasviðs Háskóla Íslands. Tilgangur hinnar endurteknu könnunar var prípættur. Í fyrsta lagi pótti, nú sem fyrr, mikilvægt að meta stöðu nema sem hefja nám við háskóla. Í öðru lagi var einkar forvitnilegt að bera saman árangur nýnema í kennaranámi árin 1992 og 2014. Í priðja lagi var með könnuninni sóst eftir vísbendingum sem að gagni mættu koma við uppbyggingu kennaranáms, enda mikilvægt við skipulag stærðfræðinámskeiða í kennaranámi að hafa upplýsingar um forpekkingu nemenda.

\section{Baksvið}

\section{Kennaranám og undirbúningur fyrir stærðfræðikennslu}

Kennarar hafa löngum pótt gegna mikilvægu hlutverki í samfélaginu. Árið 2014 gaf Mennta- og menningarmálaráđuneytið út Hvítbók um umbectur i menntun og er par vísað í skýrslu frá McKinsey (Barber og Mourshed, 2007) og einnig í Hargreaves og Fullan (2012) pví til staðfestingar að menntun og störf kennara séu peir pæettir sem mest áhrif hafi á frammistöðu menntakerfis (Mennta- og menningarmálaráđuneytið, 2014, bls. 38).

Stærðfræðikunnátta verðandi og starfandi stærðfræðikennara hefur verið rannsökuð á alpjóðavísu. Ball (1990) rannsakaði stærðfræðikunnáttu kennaranema við 11 kennaramenntunarstofnanir í Bandaríkjunum. Hún komst að peirri niðurstöðu að sú stærðfræðipekking sem kennaranemar byggju yfir úr fyrra námi væri ófullnægjandi sem undirbúningur pess að kenna stærðfræði til skilnings. Fjölmargar aðrar rannsóknir hafa verið gerðar á stærðfræðipekkingu verðandi kennara, bæði hvað varðar einstök stærðfræðileg atriði svo sem almenn brot en einnig varðandi almenna stærðfræðikunnáttu og kennslufræðilega fagpekkingu í stærðfræði. Dannig fjölluðu Goulding, Rowland og Barber (2002) um veikleika í stærðfræðiskilningi hjá kennaranemum og um tengsl stærðfræðibekkingar kennaranema við skipulag og framkvæmd kennslu í vettvangsnámi. Pau komust að pví að nokkuð skorti á stærðfræðilegan skilning kennaranemanna og að óöryggi í faggreininni tengdist lélegu skipulagi og lélegri kennslu. Villarreal, Albarracín og Gorgorió (2017) könnuðu pekkingu 241 kennaranema við háskólann í Barcelona á grundvallarstærðfræði (e. fundamental mathematical knowledge) sem er sá bakgrunnur í stærðfræði sem vænst er að byrjendur í kennaranámi hafi og sem talinn er nauðsynlegur til að kennaranemar hafi gagn af námskeiðum á sviði stærðfræði og stærðfræðimenntunar. Meginniðurstaða peirra var að nokkuð skorti á að kennaranemarnir hefðu pessa pekkingu og í sama streng tóku Linsell og Anakin (Linsell og Anakin, 2012).

Mikið hefur verið fjallað um pá pekkingu á innihaldi og kennslufræði stærðfræði sem nauðsynleg er til að sinna kennslu í stærðfræði, til dæmis komust Wilson, Floden og Ferrini-Mundy (2002), að peirri niðurstöðu, eftir að hafa rýnt í rannsóknir fjölmargra fræðimanna, að undirbúningur stærðfræðikennara væri oft ófullnægjandi, peir hefðu vissulega oftast náð tökum á grunnatriðum en skorti oft dýpri skilning. Ball, Hill og Bass (2005), lýstu nauðsyn pess að kennarar kynnu stærðfræði með pessum hætti:

Dó að stærðfræði sem slík sé bæði fáguð og yfirleitt sett fram á skipulegan hátt, pá er sú stærðfræðipekking sem nemendur setja fram oft ófullkomin og torskilin. Flestir aðrir purfa aldrei að kljást við slíka framsetningu á stærðfræði en kennarar eru í peirri sérstöku stöðu að purfa sem fagmenn að grandskoða, túlka, leiðrétta og auka við pekkingu sem pannig er fram sett (Ball o.fl., 2005, bls. 17). 
Rannsóknir benda einnig til að jákvæð tengsl séu á milli pekkingar kennara í stærðfræði og námsárangurs nemenda peirra í stærðfræði (Baumert o.fl, 2010; Hill, Rowan og Ball, 2005).

Kennaraháskóli Íslands, síðar Menntavísindasvið Háskóla Íslands, tók við af Kennaraskóla Íslands á áttunda áratug síðustu aldar. Segja má að breytingar á skipulagi grunnskólakennaranáms par hafi verið alltíðar. Kennaranám á háskólastigi var fyrst skipulagt sem priggja ára nám en tekur nú fimm ár. Umfang stærðfræði hefur verið breytilegt. Árið 1996 voru skyldunámskeið í stærðfræði og stærðfræðimenntun ígildi 6 ECTS (3 eldri einingar), árið 2002 voru pau ígildi 8 ECTS en árin 2007-2010 voru engin skyldunámskeið í stærðfræði. Í núverandi fimm ára námi er eitt 10 ECTS stærðfræðinámskeið í skyldu (Háskóli Íslands 2008, 2015; Kennaraháskóli Íslands, 1996, 2002). Ef undan eru skilin pau ár pegar engin stærðfræði var skylda lætur nærri að stærðfræði hafi numið 3-4\% af námseiningum kennaranáms á pessu tímabili. Kennaranemar velja sér kjörsvið og stærðfræði hefur ávallt verið par á meðal, en meirihluti kennaranema velur ekki stærðfræði sem sérhæfingu. Dað er pví ljóst að stærðfræðikunnátta flestra grunnskólakennara er að megninu til sú kunnátta sem peir afla sér ádur en peir hefja eiginlegt kennaranám. Upplýsingar um forpekkingu nýnema í kennaranámi eru mikils virði og eðlilegt að taka mið af peim við skipulag stærðfræðinámskeiða í kennaranámi.

Í skýrslu samstarfsnefndar Háskólans á Akureyri, Háskóla Íslands og Kennaraháskóla Íslands um kennaramenntun er meðal annars fjallað sérstaklega um stærðfræðimenntun (Háskólinn á Akureyri, Háskóli Íslands og Kennaraháskóli Íslands, 1997). Dar kemur fram að 9,8\% útskrifaðra kennaranema frá KHÍ á árunum 1987-1997 hafi lokið stærðfræði sem sérhæfingu og lögð er áhersla á að úrbætur purfi. Í fylgiskjali (nr. 5) með peirri skýrslu segir: „Dótt augljóst sé varðandi stærðfræði og náttúrufræði að margt purfi að skoða er jafnljóst að gefa parf kennaramenntun í pessum greinum mun meiri gaum en verið hefur og styrkja bæði grunnmenntun allra kennara og endurmenntun starfandi kennara á pessum vettvangi“. Í fylgiskjalinu er jafnframt reynt að bera saman kennslumagn greina í reynd (1991-1992) og valgreinabakgrunn útskrifaðra kennaranema og sést greinilega að sá samanburður er sérlega óhagstæður fyrir stærðfræði.

Árið 1998 ritar nefnd á vegum menntamálaráđuneytisins skýrsluna Markmið starðfreðikennslu i grunnskólum og framhaldsskólum (Reynir Axelsson, 1998). Í fyrsta kafla hennar er fjallað um meginsjónarmið sem gæta parf að pegar sett eru markmið stærðfræðikennslu og segir meðal annars, að eigi nemi að ná fullu valdi á einhverri stærðfræði sé nauðsynlegt að kenna honum töluvert meira. Í öðrum kafla sömu skýrslu er fjallað um hvernig umræddum markmiðum verði best náð og lagt er til að stærðfræðimenntun stærðfræðikennara verði efld verulega.

Samkvæmt athugun á menntun stærðfræðikennara í grunnskólum, sem menntamálaráðuneytið gerði árið 2005, reyndist u.p.b. helmingur peirra sem kenndu stærðfræði í 7.-10. bekk vera grunnskólakennarar með almennt kennarapróf, en innan við priðjungur hópsins var grunnskólakennarar með B.Ed-próf og stærðfræði sem sérhæfingu (Menntamálaráðuneytið, 2005).

Doktorsritgerð Bjargar Jóhannsdóttur frá árinu 2013 fjallar um stærðfræðilegan undirbúning verðandi grunnskólakennara á Íslandi (Björg Jóhannsdóttir, 2013). Rannsókn hennar byggir m.a. á áđurnefndri rannsókn Ball. Björg lagði fyrir spurningalista og tók viðtöl við hóp kennaranema við Háskóla Íslands. Í ritgerðinni pykir undirbúningurinn yfirleitt ónógur og ótvírætt segir Björg að niðurstöður rannsóknar sinnar gefi til kynna að pörf sé á stærðfræðimenntun fyrir alla kennaranema á Menntavísindasviði Háskóla Íslands, ekki aðeins pá nema sem sérhæfa sig til stærðfræðikennslu.

\section{Nemar við upphaf háskólanáms}

Inntökuskilyrði umfram stúdentspróf í kennaranám við Háskóla Íslands (og áđur Kennaraháskóla Íslands) hafa stundum og stundum ekki gilt en aðsóknin ræður miklu um petta. Aðsókn að 
kennaranámi hefur minnkað, á liðinni öld voru umsækjendur oftast mun fleiri en laus skólapláss, árið 2000 var staðan til dæmis sú að 722 sóttu um nám í grunndeild en 470 voru teknir inn (Kennaraháskóli Íslands, 2000). Í seinni tíð hefur aðsókn ekki verið meiri en svo að flestir umsækjendur fá inni. Ekki gilda sérstök ákvæði um stærðfræðinám úr framhaldsskóla. Í núverandi aðgangsviðmiðum kennaramenntunar við Háskóla Íslands er mælt með að nemandi hafi lokið 10 framhaldsskólaeiningum (fein) í stærðfræði á öðru hæfniprepi í framhaldsskóla (Háskóli Íslands, 2017). Aðgangsviðmiðin eru einungis ráðgefandi fyrir nemendur og framhaldsskóla og ekki hægt að gera ráð fyrir að allir nemendur uppfylli pau.

Í sérstakri athugun sem gerð var á undirbúningi kennaranema við Kennaradeild, nánar tiltekið staðnema sem innrituðust 2006 og fjarnema sem innrituðust 2005, kom í ljós að meðaleiningafjöldi í stærðfræði úr framhaldsskóla var um 12,5 (Freyja Hreinsdóttir og Friðrik Diego, 2009). Í nýjum námskrám framhaldsskóla árin 1999 og 2011 fækkaði lágmarkseiningum í stærðfræði á stúdentsbrautum úr 12 í 6 og síðan úr 6 í 3 (5 fein) (Menntamálaráđuneytið, 1999; Mennta- og menningarmálaráðuneytið, 2012). Dað er pví líklegt að meðaleiningafjöldi í stærðfræði hafi minnkað síðan árið 2006 og muni e.t.v. minnka enn frekar. Í téðri athugun árið 2007 var árangur kennaranema á skyldunámskeiði í stærðfræði haustið 2006 borinn saman við bakgrunn úr framhaldsskóla. Fram kom afgerandi fylgni (fylgnistuðull yfir 0,5) milli árangurs og fjölda stærðfræðieininga úr framhaldsskóla en mun minni fylgni milli árangurs og einkunna úr framhaldsskóla. Af pessu mætti draga pá ályktun að undirbúningur, í einingum talið, skipti verulegu máli.

Fyrir utan fækkun skyldueininga í stærðfræði í framhaldsskólum hafa ýmsar áherslubreytingar í stærðfræðikennslu orðið í grunnskólum, t.d. er meiri áhersla á tengingu stærðfræði við daglegt líf í námskrá grunnskóla árið 1999 en í námskrá 1989 (Menntamálaráđuneytið, 1989, 1999) og meiri áhersla er nú á skilning nemenda frekar en pjálfun í beitingu reiknirita.

Nýnemar við Verkfræði- og náttúruvísindasvið Háskóla Íslands hafa um árabil preytt svokallað könnunarpróf í stærðfræði, birtist grein um pað í Tímariti um menntarannsóknir árið 2013 (Anna Helga Jónsdóttir o.fl., 2013) og kemur par fram að innan við helmingur nemenda nær 50\% árangri. Pá er tekið fram að umfang fyrra stærðfræðináms ráđi miklu um árangur, meðal annars er ályktað að nemendur purfi að hafa lokið tilteknum fjölda stærðfræðiáfanga í framhaldsskóla til að standast kröfur Verkfræði- og náttúruvísindasviðs í stærðfræði (bls. 22).

\section{Könnunin}

\section{Markmið}

Eins og fram kemur í inngangi var tilgangur könnunarinnar árið 2014 fólginn í premur páttum, að nokkru leyti samofnum. Með könnuninni er leitast við að svara eftirfarandi:

1. Hver var stærðfræðikunnátta nýnema haustið 2014?

2. Er stærðfræðikunnátta nýnema árið 2014 sambærileg við stærðfræðikunnáttu nýnema árið 1992?

3. Er umfang stærðfræði í kennaranámi í rökréttu samræmi við mat á stærðfræðikunnáttu nýnema?

Í áðurnefndri skýrslu um könnunina 1992 rituðu höfundar: „Megintilgangurinn með könnuninni var að kanna hversu vel nemum í KHÍ, peim sem ekki höfðu lokið stærðfræðiáföngum við skólann, gengi að leysa fáein hefðbundin verkefni úr einfaldri stærðfræði. Stærðfræðikennurum við skólann hefur virst að margt sem varðar stærðfræði og kennaranemar ættu að kunna skil á sé peim alls ekki tamt, og með könnuninni var vonast til að innsýn fengist í vandamálið, eða öllu heldur að mat fengist á pað hvort um vandamál væri að ræða“ (bls. 1). 


\section{Pátttakendur}

Árið 1992 voru pátttakendur 85 talsins (skráðir nemendur voru 101) en árið 2014 voru peir 43 (sem er um helmingur virkra nemenda 1 árganginum). Dað voru pví næstum tvöfalt fleiri pátttakendur í fyrra skiptið. Haldgóðar skýringar á tiltölulega slakri pátttöku árið 2014 liggja ekki fyrir. Könnunin var vissulega tilgreind á stundatöflu og hennar getið í kynningu deildarforseta. Dræm pátttaka er pó ekki talin hafa afgerandi áhrif á niðurstöður. Ekkert bendir til pess að árangur fjarstaddra nemenda hefði almennt verið betri, nærtækara er að peir sem kjósa að taka ekki pátt í stærðfræðikönnun séu verr undirbúnir í stærðfræði en peir sem mæta, en hér verður ekki fengist frekar við slíkar vangaveltur. Pátttakendur virtust hafa eðlilegan áhuga á verkefninu og sinna pví samviskusamlega til enda. Einföld athugun sýnir að fjöldi réttra svara við seinni hluta verkefnisins (spurningum 16-30) var heldur meiri en fjöldi réttra svara við fyrri hluta bess (spurningum 1-15) svo ekkert benti til pess að pátttakendur hefðu lagt sig minna fram eftir pví sem leið á könnunina. Umtalsverður hluti pátttakenda spurðist fyrir um árangur sinn í tölvupósti innan fárra daga sem sýnir áhuga peirra.

\section{Spurningalistinn}

Spurningarnar (dæmin) eru 30 talsins, allt krossaspurningar (sjá viðauka). Fjöldi svarmöguleika er frá premur til sex. Á spurningalistanum er dæmum hvorki raðað eftir flokkum né pyngd. Fram hefur komið að nákvæmlega sami spurningalisti var notaður árin 2014 og 1992. Dess er pó að geta, að árið 1992 reyndist ein spurning gölluð, rétt svar hafði fallið niður. Detta var leiðrétt í spurningalista ársins 2014. Forkönnun var gerð meðal kennaranema og stuðst við pá forkönnun við gerð spurningalistans árið 1992.

Spurningarnar má flokka í eftirtalda fimm efnisflokka og getur sú flokkun talist tiltölulega hefðbundin, yfirskrift flokka er eins og í námskrá 1989 (Menntamálaráðuneytið, 1989). Fjöldi spurninga úr hverjum flokki er mismunandi.

1) Tölur, alls fimm dæmi (nr. 2, 4, 5, 13 og 21).

2) Reikningur og algebra, alls 13 dæmi (nr. 1, 3, 6, 7, 8, 9, 10, 11, 15, 22, 23, 26 og 28).

3) Rúmfræði, alls 6 dæmi (nr. 12, 14, 16, 17, 24 og 29).

4) Líkindareikningur og tölfræði, alls 3 dæmi (nr. 18, 19 og 27).

5) Rökfræði, alls 3 dæmi (nr. 20, 25 og 30).

Eins og ofangreind flokkun gefur til kynna er spurningalistinn fyrst og fremst hugsaður sem verkefni úr grunnskólastærðfræði. Að auki eru spurningar sem reyna á almenna ályktunarhæfni. Öll stærðfræðihugtök sem koma fyrir teljast til algengra hugtaka úr grunnskólastærðfræði, pau helstu eru: Brot, summa, veldi, prósenta, kvaðratrót, flatarmál, hringur, ferningur, líkur, oddatala, jákvæð tala og neikvæð tala, samsíða. Séu viðfangsefni spurningalistans borin saman við stærðfræðinámsefni grunnskóla, má segja að sum verkefnin gætu átt heima á miðstigi, en meirihluti peirra á unglingastigi.

Kappkostað var að hafa orðalag spurninga einfalt, hversdagslegt og hnitmiðað, fyrirmæli spurninga eru yfirleitt aðeins ein til prjár línur. Um helmingur spurninganna er settur fram sem „,bein dæmi“ (leggið saman, hvert er flatarmálið?, o.s.frv.), hinn helminginn má kalla „orðadæmi“. Sem dæmi um hið fyrrnefnda er verkefni 1 , pað er einfaldlega: 5/8 +5/6 er sama og (og síðan gefnir fimm valkostir á svari). Sem dæmi um orðadæmi má nefna spurningu 11: Í mjólkur- og brauðbúðinni keyptu dag einn 84 viðskiptavinir mjólk, 78 keyptu brauð. 44 viðskiptavinanna keyptu bæði mjólk og brauð. Нvað voru viðskiptavinirnir margir alls? Auk hins stutta texta fylgdu einfaldar skýringarmyndir með fjórum af rúmfræðidæmunum.

Til að leysa verkefnin parf lágmarksskilning á táknmáli stærðfræðinnar, táknmáli sem lýtur 
að hefðbundnum reikniaðgerðum; samlagningu, frádræetti, margföldun og deilingu sem og forgangsröð aðgerða, en einnig reynir á skilning á veldarithætti. Að langmestu leyti er sneitt hjá minnisatriðum. Í einu dæmi reynir á reglu Pýpagórasar.

Engin verkefnanna krefjast langra útreikninga. Stundum er beðið um beina útreikninga, sbr. spurningu 2: $3-1^{2}-(-2)+(-3)^{3}$ er jafnt og ... . Einnig eru dæmi um að óbeint sé farið fram á útreikninga, eins og í spurningu 26: $250 \mathrm{gr}$ af vörutegund A kosta $200 \mathrm{kr}$. $400 \mathrm{gr}$ af vörutegund B kosta 300 kr. 500 gr af vörutegund C kosta 350 kr. Að pessu gefnu er spurt hvaða vörutegund sé hagkvæmast að kaupa.

Hvergi á spurningalistanum kemur flókin algebra við sögu. Dað reynir á lagni við meðferð bókstafa 1 spurningu 6 , par sem beðið er um að einfalda stæðuna $a^{2}(b+a)-b\left(a^{2}-a\right)$. Spurning 10 var sömuleiðis úr algebru: Ef $(3 x+5) / x=4$ hvað er pá $2 x+5$ ?

Ofangreindir eiginleikar spurninga stuðla allir að réttmæti könnunarinnar. Eftir að könnun var lögð fyrir var gerð stutt tölfræðiathugun á niðurstöðum sem leiddi ekkert athugavert í ljós. Svör við einni spurningu gefa neikvæða fylgni við heildarniðurstöður. Cronbachs alpha (mælikvarði á innra samræmi) var 0,83 sem telst gott.

\section{Framkvæmd}

Dann 26. ágúst 2014 var spurningalistinn lagður fyrir nemendur á 1. ári við Kennaradeild Menntavísindasviðs Háskóla Íslands. Leyfi hafði fengist frá deildarforseta til að leggja pessa könnun fyrir og var hún á stundatöflu fyrir staðlotu hjá viðkomandi nemendum. Könnunarinnar var getið í kynningu deildarforseta sem fram fór daginn áður. Áður en spurningalistinn var lagður fyrir voru helstu skipulagsatriði útskýrð. Dátttakendur voru beðnir um að skrá nöfn sín, en petta var einungis gert til að peir gætu fengið upplýsingar um árangur sinn, ef peir vildu. Könnunin samanstóð af 30 spurningum úr grunnskólastærðfræði. Allar spurningarnar voru krossaspurningar og í öllum tilvikum var eitt svar rétt. Ef pátttakandi taldi sig alls ekki vita rétt svar við tiltekinni spurningu var hann hvattur til pess að sleppa pví að svara henni fremur en að giska á svar. Vasareiknar eða önnur hjálpargögn voru ekki leyfð. Gefin var ein og hálf klukkustund til að svara könnuninni, sem reyndist í öllum tilfellum nægur tími. Árangur var ekki á nokkurn hátt tengdur námsmati og úr könnuninni var ekki unnið á persónugreinanlegan hátt. Pá var pess getið hverjir væru höfundar spurninga.

Við úrvinnslu niðurstaðna gaf áðurnefnd efnisflokkun spurninga tækifæri til samsvarandi greiningar á niðurstöðum. Pá er mjög einfalt að gera samanburð á niðurstöðum 1992 og 2014, par sem um sömu spurningar er að ræða bæði skiptin, samanburð milli hópanna má sömuleiðis að sundurliða eftir efnisflokkum.

Fram hefur komið að dæmum var ekki raðað eftir pyngd, en áður en dæmin voru lögð fyrir árið 1992 var reynt að leggja mat á pyngdarstig peirra með pví að aðstandendur áætluðu árangur pátttakenda spurningu fyrir spurningu. Gerði hvor spurningahöfundur sína spá og var tekið meðaltal. Inn í slíka áæetlun fléttast nokkur matsatriði eins og hvort í eðli sínu sé um að ræða einfalt (auðleyst) atriði, spáin er semsagt mat höfunda á flækjustig dæmanna. Pá hljóta tengsl við grunnskólanámsefni að skipta máli, til dæmis má heita öruggt að allir hafi lært að leggja saman almenn brot og jafnframt má gera ráð fyrir að petta atriði sé vel æft, svo tiltölulega líklegt er að mestur hluti nemenda hafi getu til að leysa pannig dæmi (sbr. dæmi 1). Á hinn bóginn er meðhöndlun velda og kvaðratróta veigaminna atriði í grunnskólanámi og árangur í slíkum dæmum væntanlega síðri (sbr. dæmi 9 og 23). Við gerð spár á sínum tíma töldu höfundar sig búa að áralangri reynslu af stöðu kennaranema í stærðfræði og spáðu ekki af bjartsýni.

Til að grennslast fyrir um hugsanleg áhrif breytinga á viðhorfum og kennsluháttum í stærðfræði á árangur í könnuninni voru spurningar flokkaðar á mismunandi vegu og skoðaður munur 
á árangri árin 1992 og 2014. Annars vegar var dæmum könnunarinnar skipt í tvo jafnstóra flokka, í fyrri flokkinn sett pau sem reyna tiltölulega mikið á reiknikunnáttu, en í síðari flokkinn pau sem reyna tiltölulega mikið á stærðfræðilegan skilning. Áðurnefnt dæmi um vörutegundir fellur til dæmis í fyrri flokkinn, reynir tiltölulega mikið á reiknikunnáttu, en spurningin um viðskiptavini í mjólkur- og brauðbúðinni fer í síðari flokkinn, reynandi fremur á skilning. Til fyrri gerðar töldust pessi dæmi: 1, 2, 3, 4, 6, 7, 9, 10, 12, 13, 17, 21, 23, 24, 26 og til síðari gerðar töldust pessi dæmi: 5, 8, 11, 14, 15, 16, 18, 19, 20, 22, 25, 27, 28, 29, 30. Hins vegar var sérstaklega skoðað hvort munur á gengi nemenda árin 1992 og 2014 væri mismikill eftir pví hvort verkefnin hefðu einhverja tengingu við raunveruleikann eða væru tiltölulega óhlutbundin (reikningseða algebrudæmi). Вæði dæmið um vörutegundir og dæmið um viðskiptavini í mjólkur- og brauðbúðinni teljast hafa tengingu við raunveruleikann, en dæmið um samlagningu brota telst hreint reikningsdæmi.

Verkefni sem tengjast raunveruleikanum teljast: 3, 8, 11, 15, 18, 19, 20, 21, 22, 25, 26, 27, 30 og verkefni sem teljast óhlutbundnari: 1, 2, 4, 5, 6, 7, 9, 10, 13, 23, 28. Rúmfræðidæmin voru ekki tekin með í pessum samanburði.

\section{Niðurstöður}

Hér eru fyrst tilgreindar niðurstöður úr könnuninni sem gerð var árið 2014, pær sýndar eftir einstökum dæmum og eftir efnisflokkum. Dá má sjá árangur einstakra pátttakenda. Síðan eru settar fram töflur sem sýna samanburð hópanna 2014 og 1992. Dessi samanburður er gerður eftir einstökum dæmum og eftir efnisflokkum. Ennfremur eru niðurstöður athugaðar miðað við tvískiptingu verkefna 1 „,reikningsdæmi“ og „,kkilningsdæmi“ og að lokum er skoðaður sérstaklega munur á árangri við lausn verkefna sem tengjast raunveruleika og óhlutbundnari verkefna.

\section{Árangur 2014}

Haustið 2014 var fjöldi réttra svara að meðaltali 44\%. Árangur í einstökum dæmum má sjá í eftirfarandi töflu.

Tafla 1. Fjöldi réttra svara við hverju dæmi (43 pátttakendur)

\begin{tabular}{cccccc}
\hline Dæmi & Fjöldi & Dæmi & Fjöldi & Dæmi & Fjöldi \\
\hline Dæmi 1 & 23 & Dæmi 11 & 21 & Dæmi 21 & 20 \\
Dæmi 2 & 12 & Dæmi 12 & 30 & Dæmi 22 & 17 \\
Dæmi 3 & 18 & Dæmi 13 & 12 & Dæmi 23 & 3 \\
Dæmi 4 & 18 & Dæmi 14 & 33 & Dæmi 24 & 8 \\
Dæmi 5 & 19 & Dæmi 15 & 25 & Dæmi 25 & 23 \\
Dæmi 6 & 9 & Dæmi 16 & 17 & Dæmi 26 & 34 \\
Dæmi 7 & 10 & Dæmi 17 & 17 & Dæmi 27 & 17 \\
Dæmi 8 & 24 & Dæmi 18 & 34 & Dæmi 28 & 15 \\
Dæmi 9 & 5 & Dæmi 19 & 4 & Dæmi 29 & 32 \\
Dæmi 10 & 13 & Dæmi 20 & 32 & Dæmi 30 & 17 \\
\hline
\end{tabular}

Ljóst er að dæmin reyndust pátttakendum mispung, allt frá pví að aðeins 3 pátttakendur (7\%) svari rétt í dæmi 23 til pess að 34 pátttakendur (79\%) svari rétt í dæmum 18 og 26.

Í töflu 2 má sjá hlutfall réttra svara árið 2014 í hverjum hinna fimm efnisflokka. 
Tafla 2. Hlutfall réttra svara eftir efnisflokkum

\begin{tabular}{lc}
\hline Efnisflokkur & Hlutfall réttra svara \\
\hline Tölur (alls 5 dæmi) & $38 \%$ \\
Reikningur og algebra (alls 13 dæmi) & $39 \%$ \\
Rúmfræði (alls 6 dæmi) & $53 \%$ \\
Líkindareikningur og tölfræði (alls 3 dæmi) & $43 \%$ \\
Rökfræði (alls 3 dæmi) & $56 \%$ \\
\hline
\end{tabular}

Við pví mátti búast að pátttakendur stæðu sig misvel og varð sú vissulega raunin. Hlutfall réttra svara hjá nemendum var frá 10\% til 97\%. Í töflu 3 má sjá hvernig fjöldi réttra svara skiptist.

Tafla 3. Fjöldi pátttakenda (af 43) með tiltekinn fjölda réttra svara

\begin{tabular}{cccccc}
\hline Rétt svör & Fjöldi & Rétt svör & Fjöldi & Rétt svör & Fjöldi \\
1 & 0 & 11 & 3 & 21 & 1 \\
2 & 0 & 12 & 3 & 22 & 0 \\
3 & 1 & 13 & 0 & 23 & 1 \\
4 & 0 & 14 & 2 & 24 & 0 \\
5 & 1 & 15 & 3 & 25 & 0 \\
6 & 1 & 16 & 5 & 26 & 1 \\
7 & 4 & 17 & 2 & 27 & 0 \\
8 & 2 & 18 & 3 & 28 & 0 \\
9 & 4 & 19 & 1 & 29 & 1 \\
10 & 4 & 20 & 0 & 30 & 0 \\
\hline
\end{tabular}

\section{Samanburður við árangur 1992}

Eitt markmiða könnunarinnar var að bera saman árangur pátttakenda 2014 og árangur peirra sem svöruðu sama spurningalista árið 1992. Í töflu 4 má sjá hlutfall réttra svara pessara tveggja hópa og mismun, dæmi fyrir dæmi (tekið skal fram að dæmi 12 er fellt út við samanburðinn, vegna galla sem á pví var 1992).

Tafla 4. Hlutfall réttra svara og mismunur áranna 2014 og 1992

\begin{tabular}{|c|c|c|c|c|c|c|c|}
\hline Dæmi & 2014 & 1992 & Mismunur & Dæmi & 2014 & 1992 & Mismunur \\
\hline Dæmi 1 & $53 \%$ & $79 \%$ & $-26 \%$ & Dæmi 16 & $40 \%$ & $34 \%$ & $+6 \%$ \\
\hline Dæmi 2 & $28 \%$ & $58 \%$ & $-30 \%$ & Dæmi 17 & $40 \%$ & $35 \%$ & $+5 \%$ \\
\hline Dæmi 3 & $42 \%$ & $65 \%$ & $-23 \%$ & Dæmi 18 & $79 \%$ & $87 \%$ & $-8 \%$ \\
\hline Dæmi 4 & $42 \%$ & $61 \%$ & $-19 \%$ & Dæmi 19 & $9 \%$ & $33 \%$ & $-24 \%$ \\
\hline Dæmi 5 & $44 \%$ & $33 \%$ & $+11 \%$ & Dæmi 20 & $74 \%$ & $86 \%$ & $-12 \%$ \\
\hline Dæmi 6 & $21 \%$ & $40 \%$ & $-19 \%$ & Dæmi 21 & $47 \%$ & $52 \%$ & $-5 \%$ \\
\hline Dæmi 7 & $23 \%$ & $42 \%$ & $-19 \%$ & Dæmi 22 & $40 \%$ & $42 \%$ & $-2 \%$ \\
\hline Dæmi 8 & $56 \%$ & $54 \%$ & $+2 \%$ & Dæmi 23 & $7 \%$ & $15 \%$ & $-8 \%$ \\
\hline Dæmi 9 & $12 \%$ & $18 \%$ & $-6 \%$ & Dæmi 24 & $19 \%$ & $19 \%$ & $0 \%$ \\
\hline Dæmi 10 & $30 \%$ & $56 \%$ & $-26 \%$ & Dæmi 25 & $54 \%$ & $65 \%$ & $-11 \%$ \\
\hline Dæmi 11 & $49 \%$ & $64 \%$ & $-15 \%$ & Dæmi 26 & $79 \%$ & $78 \%$ & $+1 \%$ \\
\hline Dæmi 12 & $(70 \%)$ & & & Dæmi 27 & $40 \%$ & $39 \%$ & $+1 \%$ \\
\hline Dæmi 13 & $28 \%$ & $59 \%$ & $-31 \%$ & Dæmi 28 & $35 \%$ & $69 \%$ & $-34 \%$ \\
\hline Dæmi 14 & $77 \%$ & $85 \%$ & $-8 \%$ & Dæmi 29 & $74 \%$ & $67 \%$ & $+7 \%$ \\
\hline Dæmi 15 & $58 \%$ & $76 \%$ & $-18 \%$ & Dæmi 30 & $40 \%$ & $32 \%$ & $+8 \%$ \\
\hline
\end{tabular}


Hér blasir við að árangur hópsins árið 2014 var yfirleitt lakari en hópsins 1992, nánar tiltekið var árangur hans lakari í 2/3 tilvika, hlutfall réttra svara af heild var 44\% árið 2014 en 53\% árið 1992. Sé árangur borinn saman eftir efnisflokkunum fimm (sjá töflu 5) kemur í ljós að 2014 var árangurinn lakari í fjórum flokkum af fimm. Hann var umtalsvert lakari í flokkunum „tölur“ og „reikningur og algebra“, hann var sömuleiðis lakari í flokkunum „líkindareikningur og tölfræði“ og „,rökfræði“ pó munurinn par væri minni, en í flokknum „rúmfræði“ var árangur hins vegar ögn betri árið 2014.

Tafla 5. Hlutfall réttra svara 2014 og 1992 eftir efnisflokkum

\begin{tabular}{lccc}
\hline Efnisflokkur & $\mathbf{2 0 1 4}$ & $\mathbf{1 9 9 2}$ & Mismunur \\
\hline Tölur (5 dæmi) & $38 \%$ & $52 \%$ & $-14 \%$ \\
Reikningur og algebra (13 dæmi) & $39 \%$ & $54 \%$ & $-15 \%$ \\
Rúmfræði (6 dæmi, eitt er hér fellt út) & $50 \%$ & $48 \%$ & $2 \%$ \\
Líkindareikningur og tölfræði (3 dæmi) & $43 \%$ & $53 \%$ & $-10 \%$ \\
Rökfræði (3 dæmi) & $56 \%$ & $61 \%$ & $-5 \%$ \\
\hline
\end{tabular}

\section{Fleiri sjónarhorn á niðurstöður}

Með pað í huga að hugsanlega mætti greina áherslubreytingar í stærðfræðikennslu eða próun frá 1992 til 2014 var dæmum könnunarinnar skipt í tvo jafnstóra flokka, í fyrri flokkinn sett dæmi sem teljast reyna tiltölulega mikið á reiknikunnáttu, en í síðari flokkinn pau sem teljast reyna tiltölulega mikið á skilning.

Hlutfall réttra svara samkvæmt pessari greiningu má sjá í töflu 6 (dæmi 12 er fellt út við samanburðinn).

Tafla 6. Hlutfall réttra svara 2014 og 1992 í ljósi innbyrðis flokkunar dæma

\begin{tabular}{lccc}
\hline & Árangur 2014 & Árangur 1992 & Mismunur \\
\hline Reiknikunnátta & $34 \%$ & $48 \%$ & $-14 \%$ \\
Skilningur & $51 \%$ & $58 \%$ & $-7 \%$ \\
\hline
\end{tabular}

Munur á árangri er meiri í fyrri dæmagerðinni, 14\% á móti 7\%. Af peim 8 dæmum sem heppnast betur 2014 en 1992 tilheyra 6 dæmi síðari flokknum.

Athyglisverð niðurstaða fæst ef sérstaklega er skoðaður munur á árangri 1992 og 2014 við lausn peirra verkefna sem tengjast raunveruleikanum og peirra verkefna sem eru hrein reiknings- eða algebrudæmi. Í töflu 7 er árangur sýndur miðað við pessa tvo flokka.

Tafla 7. Árangur við lausn dæma með raunveruleikatengingu og hreinna reikningsdæma

\begin{tabular}{lccc}
\hline & Árangur 2014 & Árangur 1992 & Mismunur \\
\hline Raunveruleikatenging & $51 \%$ & $59 \%$ & $-8 \%$ \\
Reikningur/algebra & $29 \%$ & $48 \%$ & $-19 \%$ \\
\hline
\end{tabular}

Fyrir báða flokka dæma er um afturför að ræða en hún er miklu minni fyrir dæmin með raunveruleikatenginguna.

Ef skoðaður er munur á frammistöðu 1992 og 2014 við lausn einstakra verkefna kemur í ljós að munurinn er mestur í verkefnum 1 (-26 prósentustig), 2 (-30 prósentustig), 10 (-26 prósentustig), 13 (-31 prósentustig) og 28 (-34 prósentustig). Dessi verkefni mæla pekkingu á almennum brotum, á neikvæðum tölum og reikningi með peim og í einu dæmanna parf að leysa algebrulega jöfnu. 
Í spurningu 1 parf að leggja saman brotin $5 / 8$ og $5 \%$ en til pess parfpekkingu sem grunnskólanemendur tileinka sér í mörgum tilfellum á miðstigi. Ef nemendur leysa petta með pví að nota minnsta samnefnara purfa peir að lengja brotin og leggja teljara saman, p.e.a.s. $5 / 8+5 / 6=15 / 24+20 / 24=$ 35/24. Árið 2014 krossa 53\% við rétt svar en 23\% nemenda krossa við svarið 10/14 sem fæst með pví að leggja saman teljara og nefnara $15 \% 8$ og $5 \%$. Til samanburðar pá krossa $79 \%$ við rétt svar árið 1992 en 10\% velja svarið 10/14 pað ár.

Í spurningu 13 á að raða premur brotum, $16 / 3,5 \%$ og 45/7 eftir stærð. Umskrift yfir í blönduð brot gefur að petta eru $51 \frac{1}{3}, 5$ 5/9 og $6 \frac{3}{7}$. Í raun parf pví einungis að bera saman $1 / 3$ og 5\%. Hér svara aðeins 28\% rétt árið 2014 en röng svör dreifast jafnt á aðra svarmöguleika.

Verkefni 2 og 28 fjalla um neikvæðar tölur og veldi. Í verkefni 2 svara 28\% rétt árið 2014 en 58\% árið 1992. Ef skoðaðir eru rangir svarmöguleikar árið 2014 virðist algengasta villan vera að telja $-1^{2}$ vera 1 en ekki -1 en 21\% velja möguleika sem bendir til pessarar villu. Verkefni 28 svara 35\% rétt árið 2014 en 69\% árið 1992. Hér er um að ræða tiltölulega einfalt verkefni par sem nýta parf sér pekkingu á borð við „margfeldi tveggja neikvæðra talna er jákvæð tala“ og „ef a er neikvæð tala pá er -a jákvæð tala“. Рað er athyglisvert að 28\% skila auðu árið 2014 en aðeins 4\% árið 1992. Í verkefni 10 purfti að leysa algebrujöfnu í einni breytistærð.

Ef skoðuð eru pau verkefni sem fleiri svöruðu rétt árið 2014 pá er mestur munur í verkefnum 5 (+11 prósentustig) og 30 (+8 prósentustig). Í verkefni 5 parf að meta stærð ferningsróta og í verkefni 30 parf að meta sanngildi nokkurra fullyrðinga út frá gefinni fullyrðingu. Í peim 5 rúmfræðiverkefnum sem voru í könnuninni var árangur betri í premur peirra enda kemur rúmfræði í heildina betur út.

\section{Umræða og ályktanir}

Einfalt mat á stöðu nýnema haustið 2014 er meðaleinkunnin 4,4. Hvað sem fyrirvörum líður verður betta að teljast lágt meðaltal á prófi sem reynir á kunnáttu í venjulegri grunnskólastærðfræði. Ríflega helmingur (58\%) pátttakenda svarar innan við helmingi spurninga rétt. Í 20 dæmum af 30 er hlutfall réttra svara innan við 50\%, svo segja má að hópurinn 2014 hafi ekki ráđið við 2/3 hluta dæmanna á spurningalistanum. Detta rímar við niðurstöður annarra (Ball, 1990; Björg Jóhannsdóttir, 2013; Goulding o.fl., 2002; Linsell og Anakin, 2012; Villarreal o.fl., 2017) enda virðist um útbreitt vandamál að ræða á alpjóðavísu.

Athygli vekur hve árangur einstaklinga var mismunandi, fjöldi réttra svara var á bilinu 3 til 29 og staðalfrávikið hátt (yfir 5).

Tæpast verður sagt að árangur sé mjög breytilegur eftir efnisflokkum. Dæmi sem snúast um tölur, reikning og algebru reynast hópnum tiltölulega erfiðust (innan við 40\% svara eru rétt), en betur tekst til við dæmi úr rúmfræði og rökfræði (um og yfir 50\% svara eru rétt).

Sé reynt að greina á milli spurninga sem annars vegar snúast fremur um reiknifærni og hins vegar um skilning, kemur nokkur munur fram, frammistaðan er töluvert betri í síðarnefndu dæmagerðinni. Munurinn er bó ekki afgerandi. Meiri munur kemur fram ef skoðuð eru pau dæmi sem hafa raunveruleikatengingu og árangur borinn saman við árangur við lausn óhlutbundnari dæma. Dessi munur er töluvert minni árið 1992 sem kann að benda til að pátttakendur árið 2014 eigi tiltölulega auðveldara með аð nálgast viðfangsefni með raunveruleikatengingu. Баð er áhugavert að skoða petta í tengslum við niðurstöður Olsen og Grønmo (2006) en greining á verkefnum PISA-rannsóknarinnar í stærðfræðilæsi, eftir pví hversu nátengd pau eru daglegu lífi pátttakenda, leiddi í ljós að Norðurlönd og enskumælandi lönd stóðu sig betur eftir pví sem verkefnin tengdust daglegu lífi meira og innihéldu minna af nákvæmum reikningum og algebru. Pau draga pá ályktun að petta stafi af áherslum í stærðfræðikennslu í grunnskóla (Olsen og Grønmo, 2006). 
Höfundar dæma reyndu árið 1992 að leggja mat á pyngd dæmanna með pví að áætla hlutfall réttra svara við hverju peirra. Í könnuninni 1992 reyndist árangur pátttakenda að jafnaði 9\% lægri en spáð hafði verið. Árangurinn 2014 reyndist að jafnaði 18\% lægri en spá gerði ráð fyrir. Áætlað var að 62\% svara yrðu rétt en reyndin varð 44\% eins og fyrr segir. Árið 2014 vék árangur minna en 5\% frá fyrirfram gerðri áætlun í 7 tilvikum af 30, var betri en áætlað í 2 tilvikum af 30 , en lakari í 21 tilviki af 30.

Upplýsingum um fyrra nám eða annan bakgrunn pátttakenda var ekki safnað í pessari könnun, en athugun á sambærilegum hópi kennaranema árið 2006 leiddi í ljós að um 2/3 peirra komu af brautum par sem vægi stærðfræði var tiltölulega lítið (Freyja Hreinsdóttir og Friðrik Diego, 2009). Fram hefur komið að athuganir benda til pess að stærðfræðikunnátta sambærilegs hóps ráðist að miklu leyti af fyrra námi, ekki síst fjölda eininga í stærðfræði í framhaldsskóla. Í ljósi pessa er nærtækt að álykta, að pátttakendur árið 2014 hafi ekki búið að miklu stærðfræðinámi úr framhaldsskóla.

Stærðfræðikunnátta nýnema mældist greinilega ekki sérlega mikil árið 2014 og forvitnilegt er að bera saman við mælingu frá 1992. Árangur pátttakenda mælist lakari árið 2014 en 1992, munur á meðaleinkunn hópanna nemur nærri einum heilum. Rétt er að ítreka, að árið 1992 var aðsókn 1 kennaranám mun meiri en 2014 og vel er hugsanlegt að val við inntöku hafi umtalsverð áhrif á niðurstöður könnunar sem pessarar. Hér verður ekki lagt mat á hve pungt sú skýring vegur.

Áherslur breytast á 22 árum, vasareiknar og hugbúnaður verða sífellt ađgengilegri og pykir sumum jafnvel orðið ástæðulaust að gera hefðbundinni reiknifærni hátt undir höfði. Árangur beggja hópa, 1992 og 2014, er slakur m.t.t. hefðbundinna reikninga og báðir hópar standa sig betur í svokölluðum skilningsdæmum. Meiru munar hjá hópnum árið 2014, en hann stendur sig pó verr en hópurinn árið 1992 í báđum hlutum. Afturförin frá 1992 er nokkuð minni pegar skoðuð eru dæmi með raunveruleikatengingu heldur en hrein reikningsdæmi.

Að staða nýnema mælist verri árið 2014 en 1992 parf e.t.v. ekki að koma á óvart. Í inngangi var minnst á PISA-rannsóknina og endurteknar mælingar hennar sem gera pátttökupjóðum kleift að fylgjast með frammistöðu eigin menntakerfis í skilgreindri hæfni yfir tíma (Almar M. Halldórsson o.fl., 2013). Vissulega eru par vísbendingar um að próun í íslensku skólakerfi sé ekki góð. Til dæmis mælist stærðfræðilæsi sem hér segir: PISA 2003: 515 stig, PISA 2006: 506 stig, PISA 2009: 507 stig, PISA 2012: 493 stig, PISA 2015: 488 stig. Pannig hefur stigum fækkað um 27 á 12 árum en miðað við pann mælikvarða sem PISA notar lætur nærri að petta svari til eins skólaárs (Menntamálastofnun, 2017).

Almennt virðast skýrslur ekki gefa til kynna sérlega góða stöðu stærðfræðinnarííslensku skólakerfi. Í nýlegri úttekt á stærðfræðikennslu á unglingastigi grunnskóla, sem unnin var fyrir Menntaog menningarmálaráđuneytið, er að vísu tiltölulega jákvæð umfjöllun um stærðfræðikennslu (Póra Pórðardóttir og Unnar Hermannsson, 2012). Í peim skólum sem eru athugaðir hafa allir stærðfræðikennarar, 30 talsins, kennsluréttindi og helmingur peirra sérmenntun í stærðfræðikennslu. Af umkvörtunarefnum í úttektinni má nefna að endur/símenntun pykir ábótavant. Nýlega var einnig gerð úttekt fyrir Mennta- og menningarmálaráðuneytið á stærðfræðikennslu í framhaldsskólum (Anna Helga Jónsdóttir o.fl., 2014). Í peirri úttekt segir fullum fetum að menntun stærðfræðikennara sé ábótavant. Fram kemur að í skólum sem tóku pátt í úttektinni sé um fjórðungur stærðfræðikennara með háskólagráðu í stærðfræði sem hlýtur að hafa neikvæð áhrif á stærðfræðikennslu í framhaldsskólum og par með pá pekkingu sem kennaranemar hafa við upphaf kennaranáms.

Dví verður auðvitað ekki svarað í einu orði hvort skipulag kennaranáms sé í rökréttu samræmi stærðfræðikunnáttu nýnema. Sé pó til grundvallar lögð sú forsenda, að eftir pví sem staða nýnema sýnist verri aukist pörf fyrir stærðfræði í kennaranámi, pá geta skipuleggjendur kennaranáms varla ályktað nema á einn veg. Porri tilvonandi kennara parf á meira stærðfræðinámi að halda, sér í lagi grunnatriðum tengdum reikningi og algebru, til að geta kennt greinina að 
námi loknu. Afar mismunandi staða nýnema eykur á vandann og gerir snúnara að skipuleggja stærðfræðinámskeið öllum kennaraefnum til gagns, sér í lagi er óvíst hve mikið getur áunnist hjá peim sem á minnstri fyrri pekkingu byggja. Viðhorf til stærðfræði eru margslungin, vel er pekkt að neikvætt viðhorf til greinarinnar hefur reynst mörgum fjötur um fót. Dað eitt að vinna á slíkum viðhorfum í kennaranámi telst mikill árangur. Til pess verður aldrei mælst, að allir verðandi grunnskólakennarar sérhæfi sig í stærðfræði, en reynslan sýnir að nánast allir geta bætt sig í stærðfræði og undantekningalítið verða viðhorf jákvæðari í leiðinni.

\section{Lokaorð}

Dó könnun sem pessi gefi augljóslega ekki fullkomna mynd af stærðfræðigetu eða stærðfræðikunnáttu pátttakenda virðist sem af henni mega draga ályktanir. Árið 1992 var staðan alvarleg og hún hefur versnað síðan.

Ekki fæst séð að tilkoma vasareikna eða aðrar áherslubreytingar 1 stærðfræðikennslu hafi gengið af hefðbundinni reiknikunnáttu dauðri, en í einföldum reiknings- og algebrudæmum mælist pó afturförin mest. Kunnátta nýnema er ekki fullnægjandi. Frekari rannsóknir á stöðunni eru mikilvægar og viðbrögð aðkallandi. Degar nánast gildir „samasemmerki“ á milli stærðfræðigetu nýnema og stærðfræðikunnáttu flestra nýútskrifaðra kennara er mikið í húfi, enda er menntun og staða kennara lykilatriði fyrir velfarnað skólakerfisins.

Í kjölfar könnunar meðal kennaranema árið 1992 skrifuðu aðstandendur í skýrslu sína: „Баð hlýtur að valda stærðfræðikennurum við KHÍ miklum áhyggjum að vita pað að árlega útskrifast nemendur með B.Ed. gráðu frá skólanum með eins veikan grunn í stærðfræði og að framan hefur verið lýst“ (bls. 10). Hafi á sínum tíma, árið 1992, pótt ástæða til að draga slíkar ályktanir, pá er enn frekar ástæða til að álykta á pessa leið um bága stöðu kennaranema 22 árum síðar.

Framhjá pví verður varla litið að hér er vandamál á ferð. Dví fer fjarri að vandinn sé óleysanlegur en hann krefst yfirvegaðra viðbragða af hálfu réttra ađila, sér í lagi hljóta skipuleggjendur kennaramenntunar að láta til sín taka. Vítahringur kunnáttuleysis í stærðfræði er ekki náttúrulögmál sem íslensku skólakerfi ber að lúta.

\section{Mathematical knowledge of students beginning their teacher education - Comparing the years 1992 and 2014}

In 1992 a group of first year students at the University of Education (now the School of Education of the University of Iceland), took a pre-assessment in mathematics. In 2014, 22 years later, the exact same questionnaire was given to a group of students entering the Faculty of Teacher Education of the School of Education.

The test consists of 30 questions or problems from standard school mathematics, involving numbers, calculations and algebra, e.g., the addition of fractions or the solution of a linear equation, problems from geometry, e.g., the estimation of the area of a square and a circle, a few problems from combinatorics, e.g., determining the number of games in a round-robin chess tournament and some word problems requiring relatively simple problem-solving skills. All the problems are multiplechoice with exactly one choice being correct.

A primary purpose of this examination was the evaluation of the mathematical skills of the students in question, when starting their Teacher Education program. Secondly, with two similar groups of students and questions being the same in both cases, a comparison of results from 1992 and 2014 seemed a highly interesting objective. Thirdly, a consideration of the results could offer indications for anyone involved in the planning of teacher education. 
Over the past decades, programs at the School of Education have frequently been revised, perhaps the greatest single change being the step from a three-year teacher education to the present five-year system. As for mathematics and mathematics education in the programs, such courses have generally amounted to 3-4\% of study units so the mathematical background of most primary school teachers is more or less their background from studies before entering the School of Education. Studies and tests at the School of Education and the School of Engineering and Natural Sciences suggest that the mathematical skill and success of university students depends on previous studies, a determining factor being the number of mathematics courses or mathematics credits taken. A recent study of the mathematical content knowledge of prospective teachers highlights the need for mathematics for all prospective teachers, not only those specializing in mathematics teaching.

This article presents some main results obtained from a pre-assessment in 2014. The percentage of correct answers to each problem is given, and these figures can be compared in a straightforward manner to similar scores from 1992. Results can also be contemplated in view of the prediction made by the two authors of the questionnaire, both mathematics teachers at the University of Education at the time.

Results from the 1992 test were generally considered to be disappointing. On most problems, student performance was below prediction. Out of the total number of answers given 53\% were correct. Results from 2014 were poorer still, with 44\% correct answers. Success did not vary considerably between fields; students did relatively better on problems from geometry and logic, and relatively worse on problems involving numbers, calculations or algebra.

An average of $44 \%$ on the test in question must be considered low, and the considerable drop from 53\% in 1992 to 44\% in 2014 is a cause for concern. It must be pointed out, that two decades ago teacher education was a popular choice for students. With an abundance of applications, student admission was subject to several conditions. This popularity of teacher education is no longer the case and in recent years most applications have been accepted. Variable conditions of admission may provide a partial explanation for the drop in mathematical performance.

From the results of a simple investigation such as this one, only modest conclusions can be drawn. In many cases, participants have not had much to do with school mathematics for years. Their performance on the pre-assessment can definitely not be considered to reflect the full extent of their mathematical competencies.

Several findings, including the results of the PISA studies, have indicated that mathematics teaching in Icelandic schools could be more effective and fruitful, and the results of this investigation add yet another uncomfortable fact. The crucial role of teachers is widely acknowledged and all due efforts to reform must certainly put the focus on teacher education.

Key words: Teacher education, mathematical knowledge, education of mathematics teachers, status test at the University of Iceland. 


\section{Um höfundana}

Freyja Hreinsdóttir (freyjah@hi.is) er dósent í stærðfræði við Menntavísindasvið Háskóla Íslands. Hún lauk BS-prófi í stærðfræði frá Háskóla Íslands árið 1986, MSprófi í stærðfræði frá Northwestern University árið 1988 og doktorsprófi í stærðfræði frá Stokkhólmsháskóla árið 1997. Helstu áhugasvið hennar eru víxlin algebra og stærðfræðimenntun, einkum notkun hugbúnaðar við nám og kennslu í stærðfræði og starfspróun kennara. Hún hefur unnið að pýðingu frjálsa hugbúnaðarins GeoGebru undanfarin 10 ár.

Friðrik Diego (fd@hi.is) er lektor í stærðfræði við Menntavísindasvið Háskóla Íslands. Hann lauk BS-prófi í stærðfræði við Háskóla Íslands árið 1982, Maîtrise-prófi í hreinni stærðfræði frá Université de Paris VI árið 1985 og námi til kennsluréttinda við Háskóla Íslands árið 1994. Helstu áhugasvið hans hafa verið algebra og talnafræði en í seinni tíð hefur hann töluvert fengist við prautastærðfræði í tengslum við íslenska og alpjóðlega stærðfræðikeppni.

\section{About the authors}

Freyja Hreinsdóttir (freyjah@hi.is) is an Associate Professor of Mathematics at the School of Education, University of Iceland. She completed a BS degree in Mathematics at the University of Iceland in 1986, an MS degree in Mathematics at Northwestern University in 1988 and a fil.dr. in Mathematics at Stockholm University in 1997. Her main interests are Commutative Algebra and Mathematics Education, especially the use of ICT in the teaching and learning of Mathematics. She is a translator of the free software GeoGebra into Icelandic.

Fridrik Diego (fd@hi.is) is an Assistant Professor at the School of Education, University of Iceland. He completed a Bachelor's degree in mathematics from the University of Iceland in 1982, a Maîtrise degree in pure mathematics from Université de Paris VI in 1985 and an Education diploma from the University of Iceland in 1994. His main interests include algebra and number theory and in later years problem solving, national and international competition mathematics.

\section{Heimildir}

Almar M. Halldórsson, Ragnar F. Ólafsson og Júlíus K. Björnsson. (2013). Lasi nemenda á sterðfreð̇i og náttúrufreðð og lesskilningur. Helstu niðurstöður PISA 2012. Reykjavík: Námsmatsstofnun.

Anna Helga Jónsdóttir, Eggert Briem, Freyja Hreinsdóttir, Freyr Pórarinsson, Jón Ingólfur Magnússon og Rögnvaldur Möller. (2014). Úttekt á storðfreðikennslu í framhaldsskólum. Reykjavík: Mennta- og menningarmálaráduneytið.

Anna Helga Jónsdóttir, Freyja Hreinsdóttir, Guðrún Geirsdóttir, Rögnvaldur Möller og Gunnar Stefánsson. (2013). Könnunarpróf nýnema í stærðfræði við Háskóla Íslands. Tímarit um menntarannsóknir, 10(1),11-28.

Ball, D. L. (1990). The mathematical understandings that prospective teachers bring to teacher education. The Elementary School Journal, 90(4), 449-466. doi:10.1086/461626

Ball, D. L., Hill, H. C. og Bass, H. (2005). Knowing mathematics for teaching: Who knows mathematics well enough to teach third grade, and how can we decide? American Educator, 29(1), 14-22.

Barber, M. og Mourshed, B. (2007). How the world's best-performing school systems come out on top. London: McKinsey Group.

Baumert, J., Kunter, M., Blum, W., Brunner, M., Voss, T., Jordan, A., .. Tsai,Y. M. (2010). Teachers' mathematical knowledge, cognitive activation in the classroom, and student progress. American Educational Research Journal, 47(1), 133-180. doi:10.3102/0002831209345157

Björg Jóhannsdóttir. (2013). The mathematical content knowledge of prospective teachers in Iceland (doktorsritgerð). Columbia University, New York. 
Freyja Hreinsdóttir og Friðrik Diego. (2009,11. febrúar). Gengi nýnema. Kynning á rannsókn á tengslum undirbúnings úr framhaldsskóla og árangurs nemenda í stærðfræði og íslensku á fyrsta ári kennaradeildar [opinn fyrirlestur í Háskóla Íslands].

Friðrik Diego og Kristín Halla Jónsdóttir. (1994). Könnun á sterðfreðigetu fyrsta árs kennaranema í Kennaraháskóla Íslands i janúar 1992 (skýrslur Rannsóknarstofnunar Kennaraháskóla Íslands, nr. 1). Reykjavík: Rannsóknarstofnun Kennaraháskóla Íslands.

Goulding, M., Rowland, T. og Barber, P. (2002). Does it matter? Primary teacher trainees' subject knowledge in mathematics. British Educational Research Journal, 28(5), 689-704. doi:10.1080/0141192022000015543a

Hargreaves, A. og Fullan, M. (2012). Professional capital:Transforming teaching in every school. New York:Teachers College Press.

Háskóli Íslands. (2008). Kennsluskrá 2008-2009. Sótt af https://ugla.hi.is/kennsluskra/index.php?tab=nam\&chapter=namsleid\&id=500000_20086\&kennsluar $=2008$

Háskóli Íslands. (2015). Kennsluskrá 2015-2016. Sótt af https://ugla.hi.is/kennsluskra/index.php?tab=nam\&chapter $=$ namsleid $\&$ id $=820166 \_20156 \&$ kennsluar $=2015 \&$ lina $=6417$

Háskóli Íslands. (2017). Kennsluskrá 2017-2018. Sótt af https://ugla.hi.is/kennsluskra/index.php?tab=skoli\&chapter=content\&id $=35102$

Háskólinn á Akureyri, Háskóli Íslands og Kennaraháskóli Íslands. (1997). Skýrsla samstarfsnefndar Háskólans á Akureyri, Háskóla Íslands og Kennaraháskóla Íslands um kennaramenntun. [Útgáfustaður ótilgreindur].

Hill, H. C., Rowan, B. og Ball, D. L. (2005). Effects of teachers' mathematical knowledge for teaching on student achievement. American Educational Research Journal, 42(2), 371-406. doi:10.3102/00028312042002371

Kennaraháskóli Íslands. (1996). Kennsluskrá fyrir almennt kennaranám 1996-1997. Reykjavík: Höfundur.

Kennaraháskóli Íslands. (2000). Ársskýrsla 2000. Reykjavík: Höfundur.

Kennaraháskóli Íslands. (2002). Náms- og kennsluskrá háskólaárið 2002-2003. Reykjavík: Höfundur.

Linsell, C. og Anakin, M. (2012). Diagnostic assessment of pre-service teachers' mathematical content knowledge. Mathematics Teacher Education and Development, 14(2), 4-27.

Menntamálaráđuneytið. (1989). Aðalnámskrá grunnskóla. Reykjavík: Höfundur.

Menntamálaráđuneytið. (1999). Aðalnámskrá framhaldsskóla: Stcerđfreðði. Reykjavík: Höfundur.

Menntamálaráðuneytið. (2005). Menntun kennara í sterðfreði- og náttúrufreððigreinum í grunn- og framhaldsskólum 2003-2004. Samantekt úr upplýsingaöflun menntamálaráduneytisins. Reykjavík: Höfundur.

Menntamálastofnun. (2017). Helstu niðurstöður PISA 2015. Sótt af https://mms.is/sites/mms.is/files/helstu_nidurstodur_pisa_2015_prent_-_loka.pdf

Mennta- og menningarmálaráđuneytið. (2012). Aðalnámskrá framhaldsskóla 2011: Almennur hluti. Reykjavík: Höfundur.

Mennta- og menningarmálaráđuneytið. (2014). Hvitbók um umbatur í menntun. Reykjavík: Höfundur.

Olsen, R.V. og Grønmo, L. S. (2006). What are the characteristics of the Nordic profile in mathematical literacy? Í J. Mejding og A. Roe (ritstjórar), Northern Lights on PISA 2003-a reflection from the Nordic countries (bls. 47-57). Kaupmannahöfn: Norræna ráðherranefndin.

Reynir Axelsson (ritstjóri). (1998). Markmið starðfreeđikennslu í grunnskólum og framhaldsskólum. Reykjavík: Menntamálaráðuneytið.

Villarreal,A.,Albarracín, L. og Gorgorió, N. (2017, febrúar). First year student teachers dealing with non-routine questions in the context of the entrance examination to a degree in primary education. CERME, 10.

Wilson, S. M., Floden, R. E. og Ferrini-Mundy, J. (2002). Teacher preparation research:An insider's view from the outside. Journal of Teacher Education, 53(3), 190-204. doi:10.1177/0022487102053003002

Dóra Pórðardóttir og Unnar Hermannsson. (2012). Úttekt á stcerðfreðikennslu á unglingastigi grunnskóla. Reykjavík: Mennta- og menningarmálaráðuneytið. 


\section{Viðauki}

\section{Spurningalisti}

1. $5 / 8+5 / 6$ er sama og

$10 / 14$

$5 / 14$

$30 / 24$

$35 / 24$

$10 / 24$

2. $3-1^{2}-(-2)+(-3)^{2}$ er jafnt og

$-21$

$-23$

$-27$

$-3$

$-1$

3. Vara nokkur kostaði 100 kr. Síðan hækkaði verðið um 10\% og nokkru síðar aftur um 10\%. Seinna lækkaði svo verðið um 10\%. Ef gert er ráð fyrir verði í heilum krónum, hvað kostar varan pá eftir pessar prjár verðbreytingar?

$108 \mathrm{kr}$.

$109 \mathrm{kr}$.

$110 \mathrm{kr}$.

$111 \mathrm{kr}$.

$112 \mathrm{kr}$.

4. Sé tölunni 2,124 breytt í almennt brot pá fæst
$531 / 250$
$248 / 1000$
$4248 / 500$
$708 / 300$

5. Merkið við pað sem er rétt

$\sqrt{36}+\sqrt{40}=\sqrt{76}$

$\square \sqrt{36}+\sqrt{40}<\sqrt{76}$

$\sqrt{36}+\sqrt{40}>\sqrt{76}$

6. $a^{2}(b+a)-b\left(a^{2}-a\right)$ er jafnt og

$a^{2}-a b$

$a^{3}-a b$

$a^{3}+a b$

$a^{2} b+a^{3}-b^{2} a+b a$

$a^{2} b+a^{3}-b^{2} a-b a$ 
7. $1 / 6+0,6$ er jafnt og
0,66
$5 / 6$
1,2
$23 / 30$
0,7

8. Ef 3 menn eru 3 daga að grafa 3 skurði, hvað eru 6 menn pá lengi að grafa 6 skurði?
1 dag
2 daga
3 daga
6 daga
9 daga

9. $5 \cdot 2^{12}-3 \cdot 2^{12}$ er sama og
$2^{13}$
$4^{12}$
$2^{11}$
$10^{12}-6^{12}$
2

10. Ef $(3 x+5) / x=4$ hvað er pá $2 x+5$ ?
9
15
$-19$
4
$-5$

11. Í mjólkur- og brauðbúðinni keyptu dag einn 84 viðskiptavinir mjólk, 78 keyptu brauð. 44 viðskiptavinanna keyptu bæði mjólk og brauð. Нvað voru viðskiptavinirnir margir alls?
74
118
206
104
162
128

12. Flatarmál hverrar rúðu á myndinni er 1.

Flatarmál príhyrningsins er 1,5

Flatarmál príhyrningsins er 2

Flatarmál príhyrningsins er 2,5

Flatarmál príhyrningsins er 3

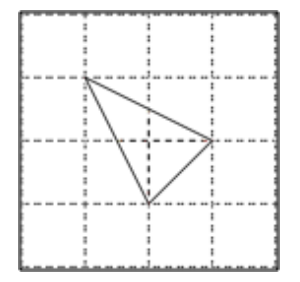


13. Raðið brotunum $16 / 3,5 \%$ og $45 / 7$ í stærðarröð.
$16 / 3<50 / 9<45 / 7$
$16 / 3<45 / 7<5 \%$
$50 / 9<16 / 3<45 / 7$
$50 / 9<45 / 7<16 / 3$
$45 / 7<16 / 3<5 \%$
$45 / 7<5 \% / 9<16 / 3$

14. Hvað eru margar hliðar, mörg horn og margar brúnir á venjulegum teningi?

6 hliðar, 8 horn og 10 brúnir.

6 hliðar, 8 horn og 12 brúnir.

6 hliðar, 12 horn og 12 brúnir.

8 hliðar, 8 horn og 10 brúnir.

8 hliðar, 10 horn og 10 brúnir.

15. Á eftirfarandi töflu má sjá árangur Jóa á prófi sem hann tók um daginn. Á prófinu voru fjögur verkefni með mismunandi vægi og gefin var einkunn fyrir hvert verkefni.

\begin{tabular}{ccc} 
Verkefni & Vægi & Einkunn \\
\hline 1 & $30 \%$ & 5 \\
2 & $10 \%$ & 7 \\
3 & $40 \%$ & 9 \\
4 & $20 \%$ & 6 \\
\hline
\end{tabular}

Hvaða einkunn á Jói að fá fyrir prófið?
5
5,5
6
6,5
7
7,5

16. Hversu margir teningar, sem eru $1 / 2$ metri á alla kanta, komast fyrir í teningi sem er $2 \mathrm{~m}$ á alla kanta?
4
8
12
16
32
64

17. Hvort hefur meira flatarmál, hringur sem er 6 sm í pvermál eða ferningur sem er 5 sm hver hlið?

Hringurinn er stærri að flatarmáli.

Deir eru nákvæmlega jafnstórir.

Ferningurinn er stærri að flatarmáli.

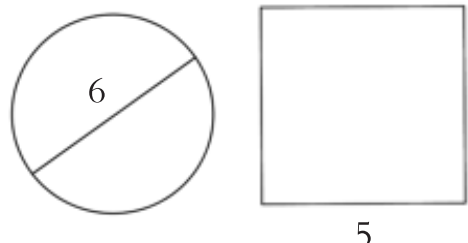


18. Í drykkjasjálfsala er unnt að kaupa kaffi, te og kókó. Velja má hvort sett er mjólk í drykkinn eða ekki og eins hvort settur er sykur í hann eða ekki. Hvað er alls unnt að velja á milli margra mismunandi drykkja úr sjálfsalanum?

19. Tíu manns taka pátt í keppni par sem sérhver peirra skal keppa einu sinni við hvern hinna. Hvað verða viðureignirnar margar alls?
20
45
50
90
100

20. Bræðurnir Gísli, Eiríkur og Helgi voru spurðir að aldri. Deir svöruðu á pessa leið:

Gísli: Ég á tvo bræður. Annar peirra er 18 ára.

Eiríkur: Ég á tvo bræður. Sá eldri er 19 ára.

Helgi: Ég á tvo bræður. Annar peirra er 20 ára.

Hvað er hver peirra gamall?

$\square$ Gísli 18 ára, Eiríkur 19 ára og Helgi 20 ára.

Gísli 18 ára, Eiríkur 20 ára og Helgi 19 ára.

$\square$ Gísli 19 ára, Eiríkur 18 ára og Helgi 20 ára.

Gísli 19 ára, Eiríkur 20 ára og Helgi 18 ára.

Gísli 20 ára, Eiríkur 18 ára og Helgi 19 ára.

Gísli 20 ára, Eiríkur 19 ára og Helgi 18 ára.

21. 7 konur voru með 7 ketti hver. Á hverjum ketti voru 7 flær. Hve mörg voru pau alls konurnar, kettirnir og flærnar?
777
749
399
343

22. Ef klukkan er núna 10.32 hvað verður hún pá eftir 1000 klukkustundir?

Hún verður 2.32

Hún verður 6.32

Hún verður 10.32

Hún verður 14.32

Hún verður 18.32 
23. $(\sqrt{32} \cdot \sqrt{3}) /(2 \cdot \sqrt{6})$ er jafnt og
$4 / \sqrt{2}$
$\sqrt{8}$
2
Ekkert af ofantöldu

24. Ef hornalína í ferningi er 2 að lengd (sjá mynd) hvert er pá flatarmál ferningsins?
1
2
3
4

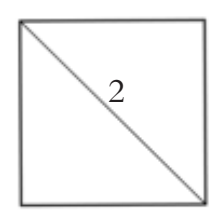

25. Ef fullyrðingin „Allir námsmenn eru duglegir“ er ekki sönn hvaða ályktun má af pví draga?

Enginn námsmaður er duglegur.

Allir námsmenn eru óduglegir.

$\square$ Sumir námsmenn eru duglegir.

Sumir námsmenn eru ekki duglegir.

26. $250 \mathrm{gr}$ af vörutegund A kosta $200 \mathrm{kr}$.

$400 \mathrm{gr}$ af vörutegund B kosta $300 \mathrm{kr}$.

$500 \mathrm{gr}$ af vörutegund C kosta $350 \mathrm{kr}$.

$\square$ Dá er hagkvæmast að kaupa vörutegund A.

$\square$ Pá er hagkvæmast að kaupa vörutegund B.

Pá er hagkvæmast að kaupa vörutegund C.

$\square$ Hagkvæmara er að kaupa vörutegund A en vörutegund C.

27. Tveimur teningum er kastað og tölurnar sem upp koma eru lagðar saman. Hvert af eftirtöldu er rétt?

$\square$ Sömu líkur eru á pví að summan sé 2 og að hún sé 4.

Talan 6 er líklegri summa en nokkur önnur tala.

Talan 7 er líklegri summa en nokkur önnur tala.

Líklegra er að summan sé oddatala en slétt tala.

28. a táknar jákvæða tölu, $b$ og $c$ tákna neikvæðar tölur. Hvert af eftirtöldu er rétt?

$a-c$ er neikvæð tala.

$c+b$ er jákvæð tala.

$a \cdot c$ er jákvæð tala.

$b+c-a$ er neikvæð tala.

$a \cdot b \cdot c$ er neikvæd tala. 
29. Ef láréttu línurnar eru samsíða hve stórt er pá hornið x?
$30^{\circ}$
$60^{\circ}$
$90^{\circ}$
$120^{\circ}$
$150^{\circ}$

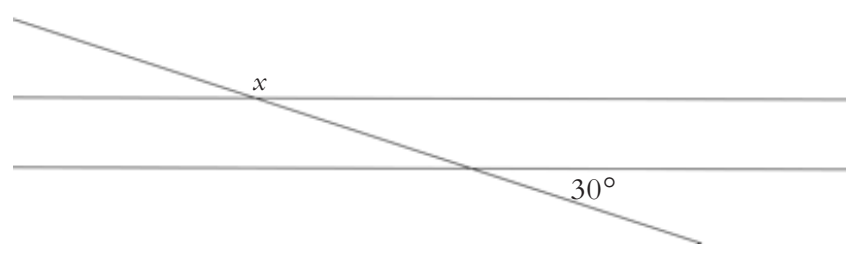

30. Gengið er út frá eftirfarandi „Ef Jóna vinnur á laugardögum pá fær hún hærra kaup“. Hver neðangreindra fullyrðinga er samkvæmt pví ósönn?

$\square$ Jóna vinnur á laugardögum en fær ekki hærra kaup.

$\square$ Ef Jóna vinnur ekki á laugardögum pá fær hún hærra kaup.

Ef Jóna vinnur ekki á laugardögum pá fær hún ekki hærra kaup.

Ef Jóna fær ekki hærra kaup pá vinnur hún ekki á laugardögum.

Freyja Hreinsdóttir og Friðrik Diego (2019).

Stærðfræðikunnátta nema við upphaf kennaranáms. Samanburður áranna 1992 og 2014

Netla - Veftímarit um uppeldi og menntun. Menntavísindasvið Háskóla Íslands.

Sótt af http://netla.hi.is/greinar/2019/ryn/04

DOI: https://doi.org/10.24270/netla.2019.4 